\title{
Field Reflections on Post-Conflict Reconstruction: The Social Imperatives of Disarmament, Demobilization and Reintegration
}

\author{
Betty O. Bigombe
}

\section{INTRODUCTION}

War does not end when the guns go silent. Christopher Cramer called this post-violence period, "the Great Post-Conflict Makeover Fantasy," and "the continuation of war by other means." Many war-like frontiers of contestation and negotiation open as soon as the guns fall silent. By the end of violent conflicts, infrastructures are broken down. People's modes of subsistence and access to medical care and education are completely shattered. War disrupts the rhythm of normal life by destabilizing the flow of essential supplies such as food and water. This is exacerbated

This chapter represents the personal views of the author.

B. O. Bigombe $(\bowtie)$

IGAD (Inter-Governmental Agency for Development) Mediation Team, Kampala, Uganda

(C) The Author(s) 2021

T. McNamee and M. Muyangwa (eds.),

The State of Peacebuilding in Africa, https://doi.org/10.1007/978-3-030-46636-7_5 
by the disruption of social and cultural securities often found in family and society. The failure to quickly ensure that necessities are restored can result in renewed violence. Post-conflict mediation interventions must, therefore, be underpinned by a singular aim: entrenching sustainable peace.

\section{Disarmament, Demobilization, ANd Reintegration}

The terms disarmament, demobilization, and reintegration (DDR) are often deployed in studies and projects relating to peacekeeping in a "postconflict" environment. Whether any place ever gets into a "post-conflict" moment is an open question. The term "reconstruction" after conflict has also been queried many times, with critics wondering whether societies ever "reconstruct" or simply "transform." 2 By the end of war, it is difficult to return to the exactness, sometimes even the semblance, of what previously existed. New centers of power emerge, and social and cultural norms are often transformed by the end of war, making any claims to "reconstruction" rather difficult. Roger Mac Ginty provides us with a definition that attempts to capture the implications behind "post-conflict reconstruction," in a more comprehensive fashion:

$[\mathrm{R}]$ econstruction encompasses short-term relief and long-term development. It extends far beyond physical reconstruction to include the provision of livelihoods, the introduction of a new or reformed type of governance and repairing fractured societal relationships. ${ }^{3}$

Critically, it emphasizes that reconstruction is not merely a technocratic exercise, but rather

it is an acutely political activity with the potential to effect profound social and cultural change. Post-war reconstruction holds the capacity to remodel the nature of interaction between the citizen and the state, the citizens and the public goods, and the citizens and the market. ${ }^{4}$

Mac Ginty, thus, seeks to draw our attention to how the lives of ex-combatants and victims can be transformed.

I intend to place my conversation on DDR into the above definition, as a process meant for both short-term relief and long-term development, but with potential for "social and cultural change." Kees Kingma, reflecting on the reintegration element, has noted that "reintegration is 
not one general process, but consists of thousands of micro-stories, with individual and group efforts, and with setbacks and successes." 5 These different stories and actors seek, among other things, to repair fractured societal relations as ex-combatants return to their villages and reunite with their families. That is, returning victims to normal civilian lives. The United Nations (UN) says of DDR:

The goal of disarmament, demobilization and reintegration (DDR) as a process of removing weapons from the hands of combatants, taking the combatants out of military structures and helping them to integrate socially and economically into society, thereby seeking to support ex-combatants so that they can become active participants in the peace process. ${ }^{6}$

In other cases, the term DDR is used for the long-term goal of ensuring permanent disarmament and sustainable peace. Often, ex-combatants are helped to enter job placement services, participate in skills training and credit schemes, and get the education needed to secure a decent living and livelihood. ${ }^{7}$

At the end of armed conflicts, different sets of victims emerge. These include the main victims of war: ordinary people caught up in the crossfire of warring factions. Many end up either as Internally Displaced Persons (IDPs) in camps or as refugees in another country. Those inside the IDP camps, including children, are often directly impacted by violence-in the form of physical injuries like bullet wounds or broken limbs-or conflictrelated stresses such as limited access to food and water or loss of parents and other family members. Children are also exposed to trauma and other forms of stress, diseases, and complications such as malnutrition. Women inside the camps also face very specific sets of challenges, including rape and forced marriages, and the resulting unwanted pregnancies. With their husbands killed in conflict, many women are forced to take on the role of breadwinner. There are also child mothers, especially victims of rape, who will be forever haunted by the horrors of war.

The aftermath of war also presents another set of victims in the form of former combatants on either side of the conflict. Child soldiers-defined as persons under 18 years of age, who are often recruited in times of conflict either as combatants or to perform other support roles ${ }^{8}$-and defeated combatants are especially prone to victimization in the postconflict period. Civil wars typically draw in fighters from many different parts of society, most of whom would never consider a career in the 
military. They have to be reintegrated back into civilian life. For those potentially interested in military careers, rarely are post-conflict armed forces able to absorb all former combatants into its ranks. Aside from budget constraints, there is a normative push to reduce the size of militaries after wartime.

This chapter focuses on post-conflict peacebuilding and reconstruction strategies after conflict has ended. It looks at processes of rehabilitation, demobilization, and reintegration for returning different categories of people victimized by the conflict to civilian life. The normative assumption underpinning the analysis below is that peacebuilding should, among other objectives, seek to return ex-combatants to an existence as close to what they experienced before violence disrupted their lives.

\section{Case Studies: Uganda and Burundi}

To highlight some of the challenges, lessons learned, and best practices, this chapter delves into two contrasting case studies of DDR: Uganda and Burundi. Specifically, this author draws heavily on her firsthand involvement in two key initiatives across these countries: the voluntary demobilization of close to 40,000 National Resistance Army (NRA) fighters in Uganda from 1993-1996, and the reintegration of child soldiers after Burundi's civil war in 2001-2004. The concluding recommendations flow from deep reflection on these difficult and complex experiences.

A main contention of the chapter is that the failure of reintegration and rehabilitation is rarely down to one big factor but instead typically involves a number of smaller failings: exclusively "rewarding" combatants in grand schemes while ignoring non-combatant victims; a mismatch between the economic potential of the environment and the intervention packages (e.g., when re-skilling is done without due regard for extant opportunities in the market); cultural nuances, including ethnic rivalries at play; and privileging seniority in economic re-empowerment (which often takes precedence over everything else). Lastly, the chapter illustrates that psycho-social support needs to move hand-in-hand with economic reconstruction. It is neither one nor the other, rather one after the other. 


\section{Uganda Veteran Assistance Programme}

Between 1992 and 1995, the Government of Uganda embarked on the demobilization and subsequent reintegration into productive civilian life of 36,358 soldiers out of an estimated 90,000-member NRA army. The project was named the Uganda Veteran Assistance Programme (UVAP). The UVAP had a dual mandate: help reduce the size of the army, thereby reducing government expenditure, and help ex-combatants return to productive civilian life as a way of transitioning from conflict to peace. The focus of the analysis here is the latter. ${ }^{9}$ The UVAP process of reintegrating the 36,358 soldiers was undertaken in three phases starting with 23,903 soldiers, then 9,308 soldiers, and finally 4,147 soldiers. ${ }^{10}$

According to some analysts, the government intended "to shift the burden of its public expenditure away from its earlier emphasis on defense and security to the promotion of social and economic development."1l But since this project followed a period of civil war, and many excombatants had been integrated into the NRA force as a strategy aimed, in part, at keeping them from returning to violence, the project was then viewed as an initiative in peacebuilding. Indeed, after 15 years of civil war, Uganda was a war-torn and ravaged economy and society.

In terms of financing, emphasis was still on security; national defense expenditure continued to rise, going from 28 percent in 1986 to 43 percent in 1991. This was unsustainable for a country just emerging from war. The World Bank noted that in the same period, capital expenditure on defense rose from 18 to 38 percent of government's contribution to development. At the time, the explanation for this increase was that:

These expenditure increases initially reflect the assimilation of defeated rebel forces and later the deliberate professionalization of the regular army through, for example, the establishment of a command structure, personnel and logistics systems, training, and the acquisition of necessary equipment and supplies as much as new recruitment. ${ }^{12}$

With most armed insurrections concluded around 1991-except Joseph Kony's Lord's Resistance Army (LRA) rebellion, which was then in its infancy-government sought to reduce expenditure on the military. Veterans, who constituted a "vulnerable group" facing myriad difficulties, would be given a chance to seek voluntary retirement from the army. The problems confronting ex-combatants were often like those of the general public: lack of shelter, lack of self-reliance skills, little money, and so on. 
But most of the ex-combatants did not enjoy the social capital of ordinary citizens, gained through being part of rural communities and comparatively broad social and cultural relations. Substantial assistance was thus required to help ex-soldiers cope with life after the military.

As a process aimed at reintegration, soldiers were to receive help toward resettling among their families and would be facilitated socially and economically into a peaceful, productive, and sustainable civilian life. The category "voluntary" and those marked for "reduction in establishment" constituted the largest percentage of veterans who would be returned to civilian life. However, it was also estimated that one in five of those who were demobilized had medical reasons for being discharged (irrespective of the other reasons offered for their demobilization). The program of reintegrating veterans back into the communities was divided into transitional safety nets including entitlements, reintegration initiatives, and administration. Each of these stages was associated with a different package ranging from cash to agricultural input. These were categorized as follows (Table 5.1).

With enormous support from the World Bank, this reintegration process worked well in the beginning but subsequently experienced several challenges. Although most problems stemmed from a lack of resources-e.g., insufficient money to buy cows, pay school fees for their children or bury their deceased kindred-some were conceptual. One erroneous assumption was that the veterans were "homogenous and their needs similar in nature. Individual problems, place of origin, period of

Table 5.1 Components of the Uganda Veteran Assistance Programme

\begin{tabular}{|c|c|c|}
\hline Transitional safety nets & Reintegration initiatives & Administration \\
\hline $\begin{array}{l}\text { Cash payment } \\
\text { Clothing allowance } \\
\text { Food allowance } \\
\text { Healthcare } \\
\text { Per diem } \\
\text { Agricultural supplies } \\
\text { Shelter (iron sheets and } \\
\text { ridges in kind, other } \\
\text { support in cash) } \\
\text { Education fees for children } \\
\text { Enhanced healthcare fund }\end{array}$ & $\begin{array}{l}\text { Severely disabled assistance } \\
\text { package } \\
\text { Scholarship training fund } \\
\text { Social communication } \\
\text { package } \\
\text { Counselling and economic } \\
\text { information support }\end{array}$ & $\begin{array}{l}\text { Discharge and transport } \\
\text { (demobilization) } \\
\text { Personal costs (UVAB and } \\
\text { districts) } \\
\text { Non-personal costs (UVAB } \\
\text { and districts) } \\
\text { Auditing and accounting } \\
\text { Monitoring and evaluation } \\
\text { Institutional development }\end{array}$ \\
\hline
\end{tabular}

Source Adapted from Nat J. Colletta, Markus Kostner, and Ingo Wiederhofer, "Case Studies in Warto-Peace Transition," World Bank Discussion Papers, no. 331 (1996), https://doi.org/10.1596/08213-3674-6 
service, and rank were all disregarded as a basis for classifying individual needs." 13

\section{The Structural Challenges with the Uganda Veteran Assistance Programme}

There were several significant challenges with the UVAP system, including challenges relating to the communities to which the veterans were being returned as well as those relating to the packages provided to veterans. Firstly, most of the packages were provided in the form of cash, not inkind as had been planned. However, most of the packages, especially those under the transitional safety nets, were too small in comparison to the needs of the veterans and often given out in installments. ${ }^{14}$ Many veterans grumbled that the USH 150,000 (roughly US $\$ 40$ in 2020) was not enough to meet their basic needs, let alone invest in something to secure their future. ${ }^{15}$

Most soldiers had health challenges, but many of them were unable to access medical care after they left the military. The number of soldiers discharged on medical grounds was about 75,000, at a time when HIV/AIDS was sweeping through Uganda like a bush fire on a windy day. The World Bank study noted that 1,696 soldiers died due to HIV/AIDS in the immediate aftermath of discharge. The challenge of accessing medical care was further complicated by the difficulties with finding food, as many had to choose between the two-medicine or food-as their financial packages were often insufficient to cover both. That the UVAP budget and cash packages did not include the veterans' families, who had hitherto received help from government, was a big oversight and shortcoming of the program. Further, the many veterans had neither education nor the requisite survival skills for the world they had been plunged into. The World Bank study noted:

Only slightly more than a quarter of phase II veterans have secondary or higher education; 12 percent had no formal education, and approximately half finished primary school. Of phase I veterans, 70 percent have not progressed beyond primary education. Although more than half of phase II veterans stated that they acquired skills while in the army, most of these skills are not marketable. Only 13 percent possess skills in mechanics, metal work, woodworking, or tailoring. Only 34 percent of phase II veterans 
possess cash cropping skills, whereas 50 percent know how to undertake subsistence farming. No more than 4 percent are familiar with cattle raising.

The study goes on to suggest that it is, consequently, hardly surprising that

71 percent of phase II veterans intended to go back to farming on resettlement. Nineteen percent envisaged activities in commerce and production. Two months after phase II resettlement, 73 percent were actually active in farming; however, 11 percent ended up as agricultural day laborers or unpaid family workers (against 1 percent intended), suggesting that around 1,000 veterans had to lower their expectations substantially. Economic reintegration, thus, proves the most elusive of all problems facing a veteran on resettlement, although personal and social attitudes can ease this process. ${ }^{16}$

The picture that emerges is one of colossal failure insofar as the economic reintegration of veterans. Many would depend on land to survive yet the UVAP failed to make land available to the demobilized soldiers or to provide them with farming knowledge and skills.

Since the start of the conflict in 1980, many of the veterans had not returned home to visit their families. Long absences made their reintegration difficult; a lot had changed while they were away. Relatives also erroneously believed that due to their military service, the returnees were comparatively well off. In other cases, the violence soldiers experienced traveled, metaphorically, back with them to their old homes, creating fear and suspicion of them in communities. This stigmatization led to high levels of frustration and depression among ex-combatants.

On land and the return to families and communities, Colleta et al. note:

Forty percent of phase II veterans did not have a house of their own on return to their home community. The majority of this group, a third of the total, lived with relatives. On the other hand, most veterans were able to secure access to land for cultivation. Only 826 cases of landlessness (or 9 percent of phase II veterans) were reported until October 1994. Around one-quarter had private land ( 23 percent), one-third had family land ( 34 percent) while another third ( 31 percent) had both family and private land. 
Under phase I, an estimated 700 veterans could not find access to land (although data may be incomplete).

Overall, the authors suggest that the number of those landless may be less than 3 percent, which

allays initial concerns expressed mainly by the donor community, although containing severe individual reintegration difficulties. A noteworthy fact is that almost one-third ( 31 percent) of phase II veterans did not have home contact since 1991. Another 22 percent visited home only once; thus, it can be assumed that knowledge about the specific location of resettlement is limited to nonexistent in many instances, aggravating the challenge of reintegration. ${ }^{17}$

In the end, frustration led many of these demobilized soldiers into either a menial existence or not returning to their communities for months after demobilization.

Although there were fewer cases of failed land access reported in the final two phases of demobilization, a number of veterans did not have land to till. In providing farm equipment, the government assumed that veterans would be returning to familial lands. Often this was not the case. Many veterans tried to avail themselves of public land through an arrangement set up by UVAB at the district level. ${ }^{18}$ Long and painstaking, the process of transferring public land proved prohibitively expensive. In cases where veterans could access family land, strife among family members often ensued.

Of deeper, societal significance was the sense that communities were being "punished twice." In contrast to Eritrea, where its soldiers in the early 1990s war against Ethiopia were celebrated as liberators, ${ }^{19}$ in Uganda, communities were negatively disposed toward returnees, who were often seen as having been responsible for widespread suffering. The idea that they should be helped (financially and otherwise) to settle back into normal life was anathema to many. This perception greatly complicated the reintegration process.

The dismal experience of the NRA's demobilization is a stark reminder that victims in communities cannot be ignored. Friction between them and veterans is the source of considerable trauma and depression, which can quietly engulf the lives of so many affected by war. 


\section{Reintegration of Burundi's Child Soldiers}

The conflict and tensions between the ethnic Hutu and Tutsi in Burundi have a long history. Mostly, they spring from the historical privileging of Tutsis over Hutus since independence. Violence escalated in 1993 when the first democratically elected president of Burundi, a Hutu, Melchior Ndadaye, was killed in a coup. This prompted the formation of Hutu militias to fight the Tutsi political opposition, which was backed by the Tutsi-dominated military. Throughout this period, both sides have recruited child soldiers into their ranks. In 2002, the Government of Burundi and then-rebel leader Pierre Nkurunziza signed a ceasefire agreement under the auspices of the African Union, which was headed by former South African President Nelson Mandela.

By the end of the fighting, UNICEF estimated that over 6,000 children had participated in these conflicts, including some as young as eight years old. ${ }^{20}$ All of them needed to be disarmed and reintegrated into civilian life. However, to properly reintegrate them, there was a need to understand their motivation for joining the armed ranks. According to Allison Dilworth, for many children, joining the conflict:

[Was] a way of countering decades of social and ethnic discrimination, and of ending years of repression by the "Tutsi army" with its history of massacring Hutu. Many volunteer recruits had been directly affected by the conflict, either seeing the murder of family and neighbours or being forced to leave their homes. Some children were reportedly encouraged by their families to join, sometimes after receiving payment or in the belief that payment would be forthcoming... Others reportedly joined partly as a result of social or peer pressure. ${ }^{21}$

There were also other forms of recruitment such as coercion and abduction from schools.

The FDD (Forces pour la Défense de la Démocratie, the military wing of the leading rebel group) recruited directly from schools, which were also attacked and destroyed, a tactic that may have facilitated the recruitment of children. An already low level of schooling dropped significantly during the war and the majority of child soldier recruits are thought not to have been enrolled in schools. 
In addition to recruitment and abduction within Burundi, Dilworth adds

...the FDD recruited child soldiers from refugee camps, particularly in Tanzania and the DRC... further recruitment and a number of mass abductions took place from schools, including the abduction of nearly 300 children from schools in Ruyigi and Kayanza provinces in November 2001. Most, but not all, returned home shortly afterwards. Children as young as eight are known to have been recruited, sometimes forcibly. ${ }^{22}$

The motivation for recruitment, and the difference in age among the child soldiers, were not factored into reintegration efforts. Those who joined after encouragement from families would be seen as heroes fighting the enemy, and their reintegration had to take an entirely different form. Those who joined when they were too young but had spent years in the conflict would have matured with exposure to adult-like practices and behaviors, and their reintegration needed to take a different approach. As the ceasefire was being signed, the Government of Burundi, with assistance from UNICEF, launched a plan to help disarm, demobilize, and reintegrate child soldiers into civilian life. As Dilworth has noted, there were serious problems with the effort, including:

[Lack] of focus in programs for the prevention of re-recruitment; treating battle-hardened 18 year olds as children rather than adults; and lack of long-term reintegration strategies including vocational training. At the community level, attitudes towards former child soldiers appear to vary from considering them as victims of the conflict, to fearing them due to their violence and brutalization through involvement in the war. Economic factors were perceived to be key to the successful and sustained reintegration of former child soldiers. ${ }^{23}$

In addition, while work was underway to identify the child soldiers, it never registered that their ethnic kin viewed them as heroes. Relatedly, attention was not paid to child soldiers whom the government had turned into local defense units called Peace Guards, yet this was equally troubling for the impact that it had on these children. This was especially important as the government took the position that it had no child soldiers in its ranks, just children "under its protection." Dilworth suggests further that:

No significant demobilization or reintegration of FDD child soldiers took place prior to these programs. Child soldiers who deserted from the FDD 
were largely incorporated into the Peace Guards militia, exposing them to new dangers and trauma. ${ }^{24}$

In most cases, more time was spent speaking with officials in the capital, Bujumbura, who did not have a good feel for what had happened on the ground, than was spent in communities where child soldiers actually were. Rarely were the child soldiers consulted on what should be done. Many times, child soldiers had been tasked to kill the "other"-for example, a Hutu grandmother of a Tutsi grandson. Yet the reintegration efforts never addressed the issue of intermarriage among the two ethnic groups, which was common. Psycho-social healing for those children who had been involved or had witnessed the killing of family members of the "other" ethnic group was never provided.

The sequencing and timeframe for the reintegration efforts was another key challenge. Often victims were asked to speak about their trauma and suffering at very short notice. For former child soldiers whose indoctrination/conscription into armed conflict often occurred over years, this was wholly misguided. Once again, as in the case of Uganda, the inordinate focus on economic reconstruction meant that key aspects of reintegration at the individual level were all but ignored.

\section{Key ReCOMmENDATIONS}

Based on the record of DDR efforts in Africa over the last 30 years, and especially the author's engagement with the two case studies outlined above, a few recommendations for improving the reintegration element of DDR are offered below.

1. Assess and balance the needs of ex-combatants. The assumption that veterans, ex-combatants, and child soldiers need financial support more than other forms of rehabilitation needs reconsideration. There is a need for a more comprehensive and integrated approach that includes personal, educational, and physical and mental health elements. Arguably, the most critical missing component in DDR efforts has been psycho-social well-being. Violent conflicts often cause considerable trauma to victims and combatants. Even if economic reintegration occurs, the mental and emotional scars of conflict will always have the potential to ruin lives if left unaddressed. This is especially important for child soldiers. 
2. Address the tenuous state of funding for disarmament, demobilization, and reintegration. Financing and resourcing of DDR efforts in Africa have been dominated by donor funding. Yet this is often tenuous and unsustainable over the long term. The overreliance on donors means that the reintegration efforts are often of a much shorter timeline than required by the scale and scope of the challenge. Appropriate re-skilling of veterans, adult education, or offers of education support to younger ex-combatants or child soldiers would be cheaper and more sustainable if African governments provided long-term funding (especially in the absence of donor funding). African countries need to find mechanisms to assume more of the financial burden of continuing reintegration efforts.

3. Reconsider a one-size-fits-all approach to disarmament, demobilization, and reintegration. Reintegration interventions have tended to assume a great deal of homogeneity of target groups. Women and men, boys and girls (child soldiers), young and old, urban and rural, all receive essentially the same assistance packages. Intervention projects should instead seek to disaggregate the different categories of people needing support or impacted by conflict, determine their needs, and structure intervention programs accordingly. In Uganda, for example, veterans returning to Buganda, where land has been properly parceled with a clear tenure system, required a different approach than what was needed by veterans returning elsewhere, where land is still communal and family-owned. Differences in cultures with respect to rituals around cleansing of evil spirits also demand proper attention, as this often determines levels of acceptance in the recipient community.

4. Implement better accounting of local opportunities and disarmament, demobilization, and reintegration. There is a need to understand better the economic and other opportunities that exist in the regions and communities to which people are being reintegrated. For example, it was an oversight for the Uganda Veteran Assistance Programme not to give sufficient farming education to veterans returning to villages, and business education to those reintegrating into urban locations. Interestingly, these items had been planned, but insufficient attention was paid to them since they were deemed of little consequence. This partly explains why some veterans quickly ran out of funds and their businesses collapsed. 


\section{Notes}

1. Christopher Cramer, Civil War Is Not a Stupid Thing: Accounting for Violence in Developing Countries (London: Hurst, 2006) 245, 249.

2. Cramer, Civil War Is Not a Stupid Thing.

3. Roger Mac Ginty, No War, No Peace: The Rejuvenation of Stalled Peace Processes and Peace Accords (London: Palgrave, 2006).

4. Mac Ginty, No War, No Peace.

5. Kees Kingma, "Post-war Demobilization and Re-integration of Excombatants into Civilian Life," Paper Presented at a USAID Conference on Promoting Democracy, Human Rights, and Reintegration in PostConflict Societies, October 30,31,1997, Bonn, Germany.

6. J. D. Mark, J. Jordans, et al., "Reintegration of Child Soldiers in Burundi: A Trace Study," Public Health 12, no. 905 (2012).

7. N. S. Anderlini and C. P. Conaway, "Disarmament, Demobilisation and Reintegration," in Inclusive Security, Sustainable Peace: A Toolkit for Advocacy and Action, November 2004 Report (London and Washington, DC: International Alert and Women Waging Peace, 2004).

8. Ilse Derluyn, Eric Broekaert, Gilberte Schuyten, and Els De Temmerman, "Post-Traumatic Stress in Former Ugandan Child Soldiers," The Lancet 363, no. 9412 (March 13, 2004): 861-863.

9. Kees, "Post-war Demobilization and Re-integration."

10. See: http://documentsl.worldbank.org/curated/en/385411468757824 $135 / \mathrm{pdf} / \mathrm{multi-page.pdf}$. Please note that the total number excombatants as accounted for in this document appears to be short by 1000.

11. Nat J. Colleta, Markus Kostner, and Ingo Wiederhofer, "Case Studies in War-to-Peace Transition: The Demobilization and Reintegration of Ex-Combatants in Ethiopia, Namibia and Uganda" (Washington: World Bank, 1996).

12. Colleta, Kostner, and Wiederhofer, "Case Studies in War-to-Peace Transition," 217.

13. Ibid., 222.

14. Ibid., 248.

15. Ibid., 248.

16. Ibid., 248 .

17. Ibid., 232 .

18. Ibid., 225.

19. Kingma, "Post-war Demobilization and Re-integration."

20. Alison Dilworth, "The CNDD-FDD (Nkrunziza) and the Use of Child Soldiers," Forum on Armed Groups and Involvement of Children in Armed Conflict (Chatteou De Bossey: Coalition to Stop the Use of Child Soldiers, 2006). 
21. Dilworth, "The CNDD-FDD", 10.

22. Ibid., 7 .

23. Ibid., 10 .

24. Ibid.

Open Access This chapter is licensed under the terms of the Creative Commons Attribution 4.0 International License (http://creativecommons.org/licenses/ by $/ 4.0 /)$, which permits use, sharing, adaptation, distribution and reproduction in any medium or format, as long as you give appropriate credit to the original author(s) and the source, provide a link to the Creative Commons license and indicate if changes were made.

The images or other third party material in this chapter are included in the chapter's Creative Commons license, unless indicated otherwise in a credit line to the material. If material is not included in the chapter's Creative Commons license and your intended use is not permitted by statutory regulation or exceeds the permitted use, you will need to obtain permission directly from the copyright holder.

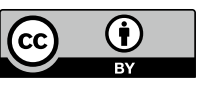

